\section{Turismo e Epidemiologia no Peru}

\section{Guilherme Antonio de Moura Costa}

RESUMO: Enfoca a problemática da situaçãa epidemiológica do Peru no período de 1981-1996. O caso do Cólera que afetou fortemente sua economia, a economia do turismo principalmente.

PALAVRAS-CHAVE: turismo e epidemiologia, cólera, economia do turismo, Peru.

ABSTRACT: This article focuses the problems aroused the epidemiological situation in Peruduring the period of 1981-1996. The case of cholera affected strongly its 1981-1996. The case of cholera affected.
economy, the economy of tourism mainly.

KEYWORDS: tourism and epidemiology, Cholera, economy of tourism, Peru

\section{Introduçāo}

Cabe ao Estado ter o controle do Turismo nacional, traduzido nos esforços que ele deve empreender, através de uma política para este setor econômico, tendo em vista que o Estado atua no turismo sempre com o intuito de obter divisas internacionais e garantir a melhoria do balanço de pagamentos, gerar empregos e impulsionar até 52 setores em atividades econômicas que são impactados pelo turismo dentro do sistema de mercado.

É natural que numa Política Nacional de Turismo, o Estado preveja e venha prover seus sítios turísticos potenciais, dos aspectos principais que a atividade turística necessita para florescer, crescer e amadurecer. Deve prover o país ou uma região de infra-estrutura de estradas, comunicações, saneamentobásico, aeroportos

1. Bacharel em Economia pela Faculdade de Ciências Econômicas de São Paulo - Fundação Álvares Penteado. Mestre em Economiapela PUCISP. Mestre em Integração da América Latina pelo PROLAM-USP. Doutorando em Turismo

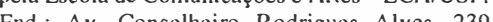

A - 04014-010 - São Paulo - SP - Brasil. Telefax: (11) 572-8820. E-mail: guilherme@sucen.sp.gov.br e até de forma pioneira e breve em hotéis, em que a iniciativa privada ainda não totalmente incentivada pelo potencial turístico da região ou país, deixa de investir nos insumos de um produto turístico, como transportes, alojamento, alimentação e entretenimento.

Tudo isso é justificável e compreendido por todos como medidas necessárias a serem previstas numa Política Nacional de Turismo, que será detalhada em ações a serem desenvolvidas dentro de um Plano Nacional de Turismo, através de programas governamentais específicos executados por cada ministério de um governo nacional, como os ministérios dos Transportes, do Saneamento Básico, das Comunicações, etc.

Assim, a preocupação clássica e única desses Planos Nacionais de Turismo tem a ver somente com a preocupação de executar ações governamentais que tenham visibilidade pública à população e gerem conforto à comodidade; e, enfím a modernidade da economia nacional a essas regiões potencialmente turísticas do país. Tudo que é perceptível pela visão humana é considerado como projeto ou programa governamental essencial, na área turística.

Todavia, há ações governamentais de programa públicos ligados, por exemplo, à área da saúde pública ambiental, de caráter preventivo, que por falta de visibilidadena "paisagem" turística e de não serperceptívelà população nativa dessa região turística, faz com que as autoridades governamentais deixem à margem dos Planos Nacionais de Turismo e de suas programações de ações intervencionistas. Essa mentalidade é típica dos países em desenvolvimento, onde por coincidência são pródigos em belezas naturais, em regiões localizadas em sua maioria nas zonas tropicais, onde o clima quente e úmido junto aos hábitos não muito higiĉnicos de vida de seus habitantes, em virtude da pobreza e da falta de instrução, permitem o surgimento de doenças tropicais transmissíveis através de insetos, bactérias ou vírus existentes de forma endêmica que circulam nessas regiões.

O Peru é um exemplo que se enquadra perfeitamente nessa descrição acima. Está localizado em zona tropical, possui inúmeras regiões de potencial turístico alto e de espécies variadas, tais como: turismo ecológico, turismo cultural e turismo de veraneio. A Amazônia peruana, os vestígios da civilização inca com seus legados culturais e arquitetônicos, o vasto litoral banhado pelo Occano Pacífico, permitem que o Peru, tenha, e verdadeiramente tem, potencial turístico suficiente para tornar o turismo como importante setor econômico, dentro da categoria de "exportações" em seu balanço de pagamentos ajudando a impulsionar seu crescimento econômico.

Porém, como já abordado, a saúde pública ambiental de caráter preventivo é minimizada em qualquer Plano Nacional de Turismo, dada a sua priorização nos países em desenvolvimento em gastar, no setordo Turismo, somente com a melhoria da "paisagem" de seus recursos naturais, não importando com ações governamentais voltadas à preservação ambiental de epidemias de doenças tropicais transmissíveis por vetores, quer sejam insetos ou mesmo seres humanos, como a doença do cólera, transmitida por um vibrião que hospedado no corpo humano, através do contato humano, passa de uma pessoa para outra numa velocidade incrível, como num inofensivo gesto social de aperto de mão, não higienizada anteriormente, sem a 
preocupação simples com o hábito de lavar as mãos com água c sabão, ou de comer alimentos crus, "in natura", mal lavados ou não fritos ou cozidos previamentc.

Quando é que as autoridades sanitárias c epidemiológicas serão ouvidas pelos policy makers do Turismo, que atuam no aparelho estatal dos governos c sĩo responsáveis pelos Planos Nacionais de Turismo?

O caso ocorrido com o Peru nos primeiros anos da década de 90, com respeito a cpidemia de cólera surgida naquele país, que praticamentc "afugentou" os turistas internacionais, no pico de transmissão dessa doença nos anos de 1991, 1992 e 1993, é exemplo vivo de nossa reflexão introdutória neste estudo.

\section{Cólera, Situação Epidemiológica e Turismo}

O Peru é um destino turístico de grande atratividade, dada a sua diversidade geográfica, riqueza arqueológica, tradiçōes e folclore. É muito mais que Machu Picchu.

Há praias paradisíacas ao longo dos scus aproximadamente 3 mil quilômetros de costa, impressionantes paisagens nas alturas dos Andes e sclva virgem no coração da Amazônia, onde os mais diversos parques nacionais, reservas nacionais c santuários da vida silvestre se convertem em lugares ideais para a prática do turismo ccológico e de aventura. Espera-se para o ano 2000, a chegada de 1 milhão de turistas.

O forte atrativo do turismo receptivo peruano, pelos estrangeiros, é o legado da civilização inca deixado em objetos de arte, trilhas pelo seu território c a arquitetura que sobreviveu e mostra um pouco da cultura e dos conhecimentos desse povo pré-colombiano que os espanhóis descobriram e que com ele se confrontaram.

Na Tabela 1 observa-se que de 1981 a 1990 a chegada de turistas estrangeiros manteve-se num patamar de 300 mil pessoas aproximadamente, sendo os anos de 1983 e 1984, o período de menor entrada, no nível aproximado de 280 mil turistas. O pico desse período (1981-1990) ocorreu em 1988, com a entrada de 359 mil turistas estrangeiros.

A partir de 1991 e nos seguintes dois anos (1992-93) houve queda brusca na entrada de turistas estrangciros no Peru: em 1991 entraram apenas 232 mil turistas; em 1992 esse número caiu para 217 mil; c, em 1993 houve pequena subida para 272 mil entradas de turistas estrangeiros.

Considerando-se o ano de 1990 como ano-referência (317 mil turistas), notase que para 1991 ( $232 \mathrm{mil}$ ) houve queda de $27 \%$ no fluxo turístico internacional em apenas 12 meses. No ano de $1992(217$ mil) a queda foi maior, representando 32\% em relação ao ano de 1990. Em 1993, apesar de uma pequena elevação na entrada de turistas (272 mil) a queda no fluxo turístico internacional ao Peru manteve-se significativa, em torno de 14,2\%. Já em 1994 (386 mil), houve um salto quantitativo enorme, em relação ao mesmo ano de 1990, representando um acréscimo de $22 \%$ de turistas estrangeiros chegados ao Peru. A partirde 1995 a tendência foi o crescimento contínuo (479 mil) e 1996 (584 mil). Assim ocorreu com a entrada de divisas estrangeiras ao Peru. De 1981 a 1990 as divisas em milhões de dólares subiram de US\$ 186 para US\$259, ou seja, 39\% em 10 anos!

TABELA 1 - INDICADORES BÁSICOS DO MOVIMENTO TURÍSTICO INTERNACIONAL NO PERIODO DE 1981-1996

\begin{tabular}{|c|c|c|c|}
\hline Ano & $\begin{array}{c}\text { Entrada de } \\
\text { Turistas (em mil) }\end{array}$ & $\begin{array}{l}\text { Divisas (em } \\
\text { milhões de } \\
\text { dólares) }\end{array}$ & $\begin{array}{c}\text { Divisas "Per Capita } \\
\text { (em dólares) }\end{array}$ \\
\hline 1981 & 335 & 186 & 555 \\
\hline 1982 & 317 & 183 & 577 \\
\hline 1983 & 273 & 153 & 560 \\
\hline 1984 & 279 & 174 & 624 \\
\hline 1985 & 300 & 189 & 630 \\
\hline 1986 & 304 & 193 & 635 \\
\hline 1987 & 330 & 211 & 639 \\
\hline 1988 & 359 & 252 & 702 \\
\hline 1989 & 334 & 247 & 740 \\
\hline 1990 & 317 & 259 & 817 \\
\hline 1991 & 232 & 225 & 970 \\
\hline 1992 & 217 & 156 & 719 \\
\hline 1993 & 272 & 215 & 790 \\
\hline 1994 & 386 & 402 & 1.041 \\
\hline 1995 & 479 & 514 & 1.073 \\
\hline 1996 & 584 & 631 & 1.080 \\
\hline
\end{tabular}

Fonte: Peru - 1997 en números - Anuário Estadístico. Consulado Geral do Peru, São Paulo.

Isso representou um grande esforço de captação de recursos internacionais injetados na economia nacional peruana. Todavia em 1991, 1992 e 1993 as divisas, assim como a entrada de turistas, caíram abruptamente. Em 1991 caiu 14\% (US\$ 225 milhões arrecadados); em 1992 a queda foi maior, em relação ao ano de 1990); $40 \%$ (US\$ 156 milhões arrecadados); e em 1993, apesar de uma pequena recuperação, as perdas foram de $17 \%$, arrecadando-se apenas US\$215 milhões.

Corroborando com essa análise das cifras de cntrada de turistas estrangeiros 
ao Peru, o ano de 1994 demonstrou também um salto significativo em divisas estrangeiras, com relação a 1990; ou seja, arrecadou-se US\$ 402 milhões, represen tando um acréscimo de nada menos de 55\%. Em 1995, arrecadou-sc US\$ 514 milhõcs e cm 1996 atirigiu-se o montante de US\$ 631 milhões.

Verifica-se facilmente que há dois momentos distintos no setor turístico peruano demonstrado pela Tabela 1: o primciro período, de 10 anos (de 1981 a 1990), e o scgundo período, de 3 anos (de 1994 a 1996). O período de intervalo (de 1991 a 1993) é o período que se pretende analisar buscando a resposta para o descmpenho medíocre tanto do fluxo turístico quanto das divisas arrecadadas.

TABELA 2 - INGRESSO DE ESTRANGEIROS, SEGUNDO O MEIO DE TRANSPORTE (1992-1996)

\begin{tabular}{l|c|c|c|c|c|c|c|c|c|c}
\hline \multirow{2}{*}{$\begin{array}{c}\text { Modali- } \\
\text { dade }\end{array}$} & \multicolumn{2}{|c|}{1992} & \multicolumn{2}{c|}{1993} & \multicolumn{2}{c|}{1994} & \multicolumn{2}{c|}{1995} & \multicolumn{2}{c}{1996} \\
\cline { 2 - 11 } & Quant. & $\%$ & Quant. & $\%$ & Quant. & $\%$ & Quant. & $\%$ & Quant. & $\%$ \\
\hline Aéreo & 156.987 & 72,5 & 198.993 & 73,0 & 282.387 & 73,1 & 356.980 & 74,6 & 425.027 & 72,8 \\
Terrestre & 54.711 & 25,2 & 68.401 & 25,2 & 98.518 & 25,5 & 116.760 & 24,4 & 154.089 & 26,3 \\
Fluvial & 1.120 & 0,6 & 1.297 & 0,5 & 1.467 & 0,4 & 1.435 & 0,3 & 1.274 & 0,2 \\
Martimo & 3.354 & 1,5 & 3.089 & 1,2 & 3.720 & 1,0 & 2.871 & 0,6 & 3.998 & 0,7 \\
Lacustre & 362 & 0,2 & 121 & 0,1 & 46 & - & 480 & 0,1 & - & - \\
\hline TOTAL & 216.534 & 100 & 271.901 & 100 & 386.138 & 100 & 478.526 & 100 & 584.388 & 100 \\
\hline
\end{tabular}

Fonte: Peru - 1997 en números - Anuário Estadístico. Consulado Geral do Peru, São Paulo.

Considerando que os turistas estrangeiros procedentes da América do Norte (EUA, Canadá e Mćxico), da Europa e a Ásia chegam ao Peru pelo transporte aéreo: e da América do Sul e Central se utilizam em grande parte do transporte terrestre, pode-se dizcr, à luz de nossas anteriores observações pela Tabela 1, que as cntradas dos turistas estrangciros no Peru, agora analisando a Tabela 2, têm nos anos de 1992 e 1993, tanto pelo transporte aérco como pclo transporte terrestre, em relação aos anos seguintes de 1994, 1995 e 1996, um volume bem inferior. Entre 1992 e 1993, a entrada de turistas por via aérea foi cm médiade 177.500 turistas, enquanto a média do pcríodo de 1994 a 1996 ( 3 anos) foi de 355.000 turistas, ou seja um acréscimo de $100 \%$ ! O mesmo ocorreu com a entrada de turistas ao Peru por via terrestre. A média dos anos de 1992 e 1993 foi de 61.500 turistas, cnquanto a média do pcríodo de 1994 a 1996 foi de 123.333 turistas, representando um acréscimo de também 100\%! Coincidência simplesmente? Não, claro que não!

Como visto na Tabela 1, os anos de 1991, 1992 e 1993 foram maus para o urismo receptivo pcruano. A Tabela 2 também confirma essa observação, tanto $\mathrm{cm}$ chegada de turistas estrangeiros quanto em divisas arrecadadas, oriundas dos gastos desses mesmos turistas estrangeiros efetuados no Peru. Ambas tabelas são coincidentes nessa má performance do turismo peruano nesse período de 1991 a 1993 (3 anos)

Então, quais as variáveis explicativas que ocasionaram essa situação, uma vez que não houve nos anos de 1991, 1992 e 1993 nenhuma catástrofe natural como terremoto, tufão ou maremoto?

A resposta é simples! Houve sim uma catástrofe de natureza biológica sobre o meio ambiente, provocada por uma epidemia de cólera dada às más condições de saúde pública do Peru, que se espalhou pela população peruana ao longo desses três anos(1991-1993), iniciando-se pelas regiões litorâneas, atingindo a capital peruana ( Lima) e expandindo-se até o interior, na região da Amazônia , fronteiriça com o Brasil.

O cólera é um vibrião de fácil transmissão, pois prolifera em ambientes insalubres e onde a população desconhecehábitos básicos de higiene. O início dessa epidemia veio através de navios da Ásia, trazidos por suas tripulações que ao se aproximarem dos portos peruanos jogaram seus dejetos próximo às praias peruanas. Ora, sabe-se que é de costume do peruano comer uma espéciede pcixe meio cru, com bastante molho de pimenta, vendido em barracas de vendedores ambulantes pelas ruas de Lima e outras principais cidades do país.

Pois bem, os dejetos dos navios de origem da Ásia continham o vibrião do cólera que sobrevive no meio ambiente por muito tempo. O pescado litorâneo absorveu esse vibrião e ao ser consumido em seu estado natural, com molho de pimenta "salsa con chile" à moda peruana. Sendo um produto alimentício cotidiano dosperuanos de classes sociais inferiores, o cólera encontrou nesse hábitat meios de sobreviver, expandir-se e criar um caos epidêmico à população peruana e aos estrangeiros que lá estavam, pois esse vibrião pode ser transmitido de um indivíduo para outro apenas por um simples aperto de mão, se esta não for lavada com água e sabão. Essa epidemia de cólera foi tão forte que durou três anos de pico no Peru e chegou a atravessar a fronteira brasileira em algumas cidades da Amazônia.

\section{Reflexos do Cólera no Fluxo Turístico Receptivo do Peru}

Para exemplificar melhor a descrição dos fatos que ocorreram com a presença do cólera no Peru entre 1991 e 1993, apresenta-se na Tabela 3 os números de casos de cólera ocorridos entre 1991 e 1996.

Pela Tabela 3, numa rápida análise, localiza-se facilmente os anos de 1991, 1992 e 1993 como os anos de pico da epidemia de cólera no Peru, divulgada na época por toda a imprensa internacional, o que reduziu o fluxo de turistas estrangeiros nessepaís. Confirmando esses dados, o fluxo de turistas em Machu Pichu apresentou no período grande redução (Tabela 4). 


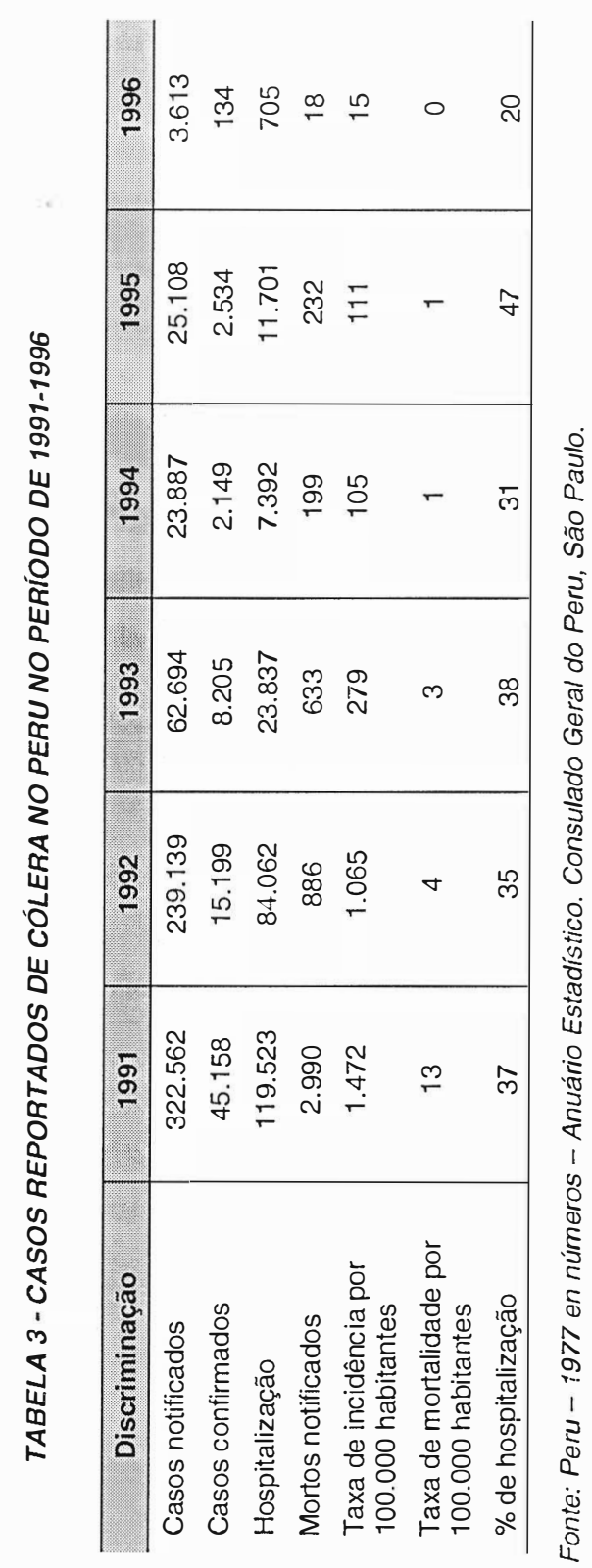

TABELA 4 - VISITANTES ESTRANGEIROS À CIDADE DE MACHU PICCHU NO PERIODODE 1987-1996

\begin{tabular}{c|c}
\hline Ano & Turistas Machu Picchu \\
\hline 1987 & 89.726 \\
1988 & 116.911 \\
1989 & 97.604 \\
1990 & 68.414 \\
1991 & 37.040 \\
1992 & 34.552 \\
1993 & 49.586 \\
1994 & 96.568 \\
1995 & 133.410 \\
1996 & 168.189 \\
\hline
\end{tabular}

Fonte: Peru - 1997 en números - Anuário Estadístico. Consulado Geral do Peru, São Paulo.

Verifica-se, assim, que os anos de menor fluxo turístico internacional a esse núcleo turístico foram os de 1991, 1992 e 1993. Tomando-se mais uma vez como marco o ano de 1990, com 68.414 visitantes estrangeiros, o ano seguinte de 1991 registrou somente 37.040 visitantes, representando uma queda de $45,86 \%$ de visitas a Machu Picchu. Em 1992 a queda no número le visitantes foi ainda maior (34.552), representando em termos percentuais uma queda de $49,50 \%$ de visitas. E finalmente em 1993, com a presença 49.586 visitantes, a que correspondeu, com referência ao ano 1e 1990, a 27,53\%. Somente a partir de 1994, quando as autoridades peruanas já estavam controlando a epidemia de cólera no país, é que as visitas turísticas a Machu Picchu, por parte dos estrangeiros subiu em relação ao ano de 1990, último ano antes lo surgimento la epidemia de cólera no Peru.

Mas o cólera não é somente uma doença que afeta e aflige o povo peruano. Assim como em todos os países tropicais, de clima quente c úmido e com população despreocupada com a higiene pessoal e coletiva (sancamento básico), representada pela falta de redes água e esgotos suficientes para atender à população dos países do Terceiro Mundo, onde a América Latina se insere; outras doenças tropicais, transmitidas no meio ambiente por vetores (insetos), como o dengue e a malária, são também importantes como presença constante lo cenário da saúde pública peruana. Basta mencionar que em 1995 houve 358.971 casos de doenças parasitárias em sua maior parte constituídos pela malária e engue, transmitidos ambos por mosquitos de espécies diferentes.

Infelizmente, os paraísos turísticos encontram-se nas zonas tropicais que favorecem a criação desses vetores, do dengue e da malária, além dessas outras 


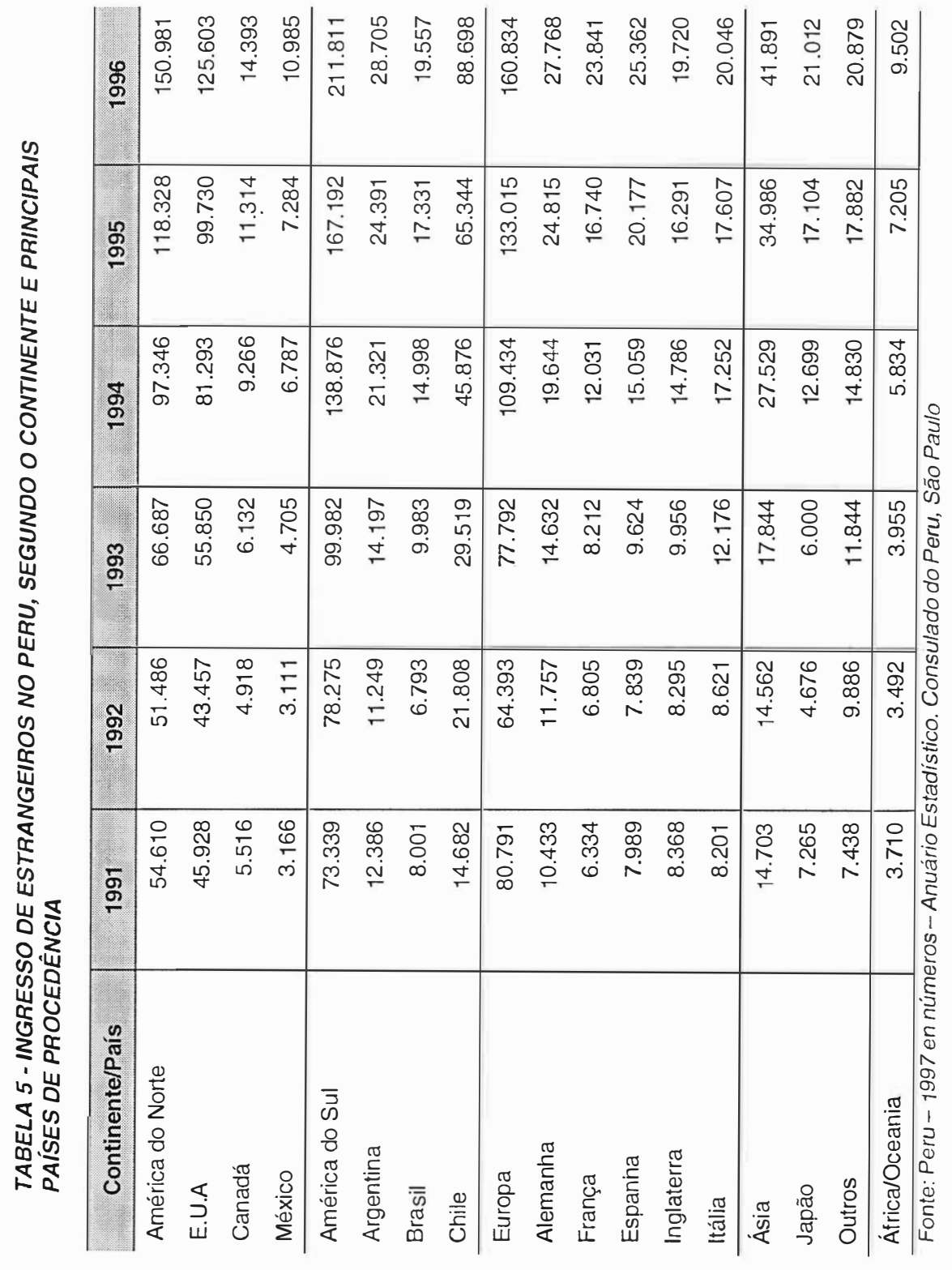

doenças, como o vibrião do cólera e o bacilos da tubcrculose e do sarampo transmitidos facilmente através de uma população de baixa instrução sanitária e de regiōes com poucos recursos de infra-cstrutura de sancamento básico. Daí, resultam as cifras alarmantes apresentadas no caso da epidemia de cólera no Pcru entre 1991 e 1993, estendendo-se em menor grau pelos anos de 1994, 1995 e 1996 (Tabela 3).

Tratando somente do aspecto turístico, bem mais ameno que o do aspecto epidemiológico do cólcra, as Tabelas 5 e 6 aprcsentam o fluxo turístico receptivo do Peru, no período de 1991 a 1996, scm contudo deixar de mostrar a sua queda de 1991 a 1993, pelas razões epidemiológicas já mencionadas - a cpidemia do cólera que afastou os turistas estrangciros para outros destinos turísticos internacionais.

Pela Tabela 5, nota-se que a América do Sul é o continentc mais representativo do turismo receptivo no Peru. A seguir vem o continente curopeu, com os principais países que escolhem o Peru como destinação turística, seguido de perto pelo continente norte-americano, onde os Estados Unidos destaca-se como o principal país emissor. Quanto ao continente asiático, o Japão tem o mesmo papel dos Estados Unidos em rclação a Ásia. A África c a Oceania, juntas, não enviam turistas ao Peru de modo representativo.

Os dados dessa tabela indicam também a grande diferença de cifras dos anos da epidemia de cólcra, dos demais anos seguintes ao controle e amenização da doença no Peru (a partir de 1994). Em 1994, tendo como referência 1991 (primeiro ano da epidemia), houve um acréscimo de visitantes estrangeiros vindos da América do Norte, da ordem de 78,25\%; da América do Sul, da ordem de 89,36\%; da Europa, da ordem de 35,45\%; da Asia, da ordem de 87,23\%; e finalmente da Africa/Oceania, da ordem de $57,25 \%$.

A Tabela 6 apresenta o ingresso de cstrangeiros no Peru, segundo o motivo da viagem no período de 1991-1996.

\section{TABELA 6 - INGRESSO DE ESTRANGEIROS, SEGUNDO O MOTIVO DA} VIAGEM (1991-1996)

\begin{tabular}{l|r|r|r|r|r|r}
\hline Motivo & 1991 & 1992 & 1993 & 1994 & 1995 & 1996 \\
\hline Turismo & 203.056 & 185.711 & 242.323 & 328.187 & 399.455 & 484.827 \\
Negócios & 2.042 & 3.772 & 3.101 & 13.552 & 21.807 & 26.169 \\
Trabalho & 18.731 & 5.557 & 4.040 & 3.790 & 3.281 & 2.115 \\
Educação & 14 & 503 & 124 & 987 & 1.681 & 2.542 \\
Residência & 7.912 & 14.515 & 19.952 & 22.353 & 24.161 & 29.286 \\
Artistas & 226 & 128 & 47 & 91 & 366 & 970 \\
Conferencistas & 15 & 1.573 & 701 & 5.097 & 7.946 & 9.581 \\
Outros(*) & 16 & 4.775 & 1.613 & 12.081 & 20.829 & 27.898 \\
\hline TOTAL & 232.012 & 216.534 & 271.901 & 386.138 & 478.526 & 584.388 \\
\hline
\end{tabular}

Fonte: Peru - 1997 en números - Anuário Estadístico. Consulado Geral do Peru, São Paulo. (*) Inclui militares, religiosos e empregados técnicos. 
Verifica-se que o motivo Turismo nos anos de 1991, 1992 c 1993 estão num patamar bem abaixo dos anos seguintes pelo motivo da epidemia do cólera, o que afastou o turista estrangeiro para outros destinos turísticos. Considerando o ingresso de turistas por Turismo em 1994, verifica-se que houve um acréscimo significativo cm relação a 1991 (ano inicial da epidemia de cólera), em torno de 66,43\% e chegando a dobrar o crescimento em 1995 (106,25\%). Em 1996, o ingresso de estrangeiros por Turismo, com relação ao mesmo ano de 1991, ultrapassou com folga a barreira dos $100 \%$ de crescimento, atingindo um incremento de $139,25 \%$. No setor de negócios, o mesmo ocorreu: 13.552 ingressos em 1994 contra 2.042 ingressos em 1991 - um incremento de 563,66\% cm 1994 em relção a 1991.

Hoje grande parte do movimento turístico mundial é decorrente de viagens turismo e de negócios, portanto os paises c regiões receptivos devem procurar ter uma situação epidemiológica soma tanto para a sua população, quando para os turistas. A retratação do fluxo turístico é imediato frente à possibilidade de contração de doenças e moléstias que em muitos casos não há remédios para sua cura, como a maioria das doenças tropicais tais como: dengue, malária, cólera, febre amarela, gripe da galinha - ocorrida recentemente em Hong Kong, onde se teve que exterminá-las todas, pois era um vírus de gripe mutante que atacava os galináceos c era mortal ao ser humano.

\section{Reflexos do Cólera na Economia do Turismo do Peru}

Para se ter uma visão geral do comportamento da economia peruana durante um pcríodo de 10 anos (1987 a 1996), dentro do qual há um período de ocorrência da epidemia do cólcra, a Tabela 7 mostra o desempenho dos setores econômicos diante da existência dessa docnça, que os afetou por um longo tempo. Tais dados destacam a queda acentuada em todos os sctores econômicos do Peru, no período de 1991, 1992 e 1993 em relação aos anos anteriores, provocada pela cxistência da cpidemia do cólera.

Considerando-se 1990 como o ano anterior a epidemia, e comparando-o com 1991, em cujo o surto epidêmico explodiu entre a população peruana, pode-se analisar, por cada setor econômico, os índices de queda na formação bruta de capital do Peru:

- Agricultura/Alimentação ........ 99,62\%;

- Transporte/Comunicação ....... 99,58\%

- Energia e Minas .................... 99,78\%

- Indust, Comércio e Turismo .. 99,55\%

- Pesca ..................................... 99,31\%;

Após o período de 1991-1993, a recuperação da formação bruta de capital por parte do governo peruano foi lenta c gradual, mas sempre sem alcançar os nívcis

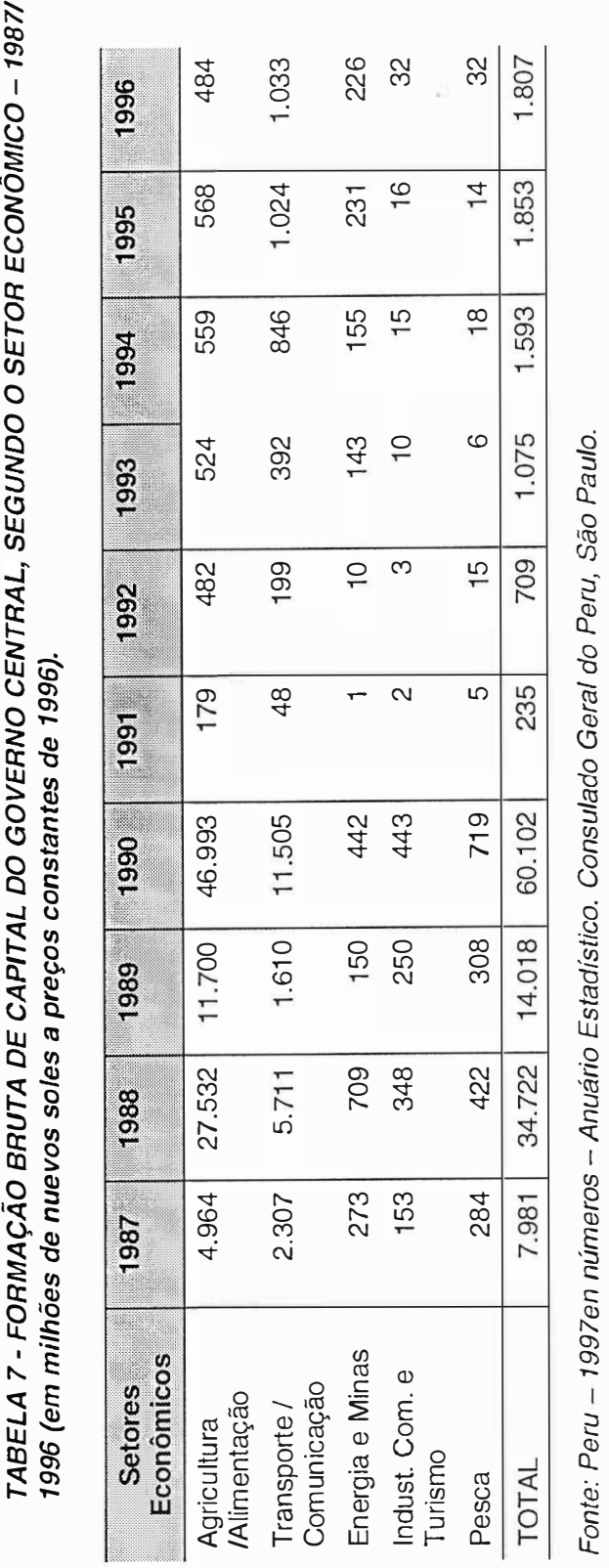


melhores dos anos de 1987 a 1990, em milhões de "nucvos soles", denominação da moeda peruana, a preços constantes de 1996.

Além disso, a imagem negativa percebida pelo turista cstrangeiro, através da deficiências de saneamento ambiental apontadas por uma situação epidemiológica grave, motivada, por cxemplo, pcla existência de uma epidemia de cólera por tode o território peruano, perdurou por muitos anos. Isso aconteceu mesmo após o reconhecimento internacional pcla Organização Mundial da Saúde (OMS) e pelas autoridades nacionais de Saúdc Pública peruanas de que passados os três anos do surto do cólera (1991-1993), cste foi controlado e mesmo erradicado; e que portanto não havia mais pretextos para se evitar o Peru como destino turístico internacional.

Ainda pelos dados da Tabela 7 percebe-se claramente que o nível das atividades cconômicas no Peru a partir de 1994 sofreu uma reação positiva, ainda que pequena em relação a 1993. No entanto, até 1996 a produção econômica peruana não tinha conseguido retomar os mesmos níveis anteriores a 1991, com destaque para o setor da Indústria, Comércio e Turismo, cujos valores (cm milhões de nuevos soles) chegaram a um décimo do que era antes dos anos do surto, ao se comparar os anos de 1987 (153 milhões) contra 1993, 1994 c 1995 (10,15 e 16 milhões respectivamente); ou o ano de 1988 (348 milhões) com o ano de 1996 (32 milhões).

A retomada da confiança dos turistas estrangeiros em relação do Peru como destino turístico percorre um longo caminho que pode significar muitos anos; ou seja, nunca a curto prazo (2 ou 3 anos); mas talvez a médio prazo (5 ou 6 anos), e com mais certeza a longo prazo (8 a 10 anos); enquanto isso a economia do turismo padece.

Portanto, há uma grande relação de interdependência entre o ato de desenvolver um planejamento turístico para uma dada região, país ou comunidade, e o ato de desenvolver um plancjamento integrado de saúde pública ambiental, como um programa de combate $\mathrm{c}$ erradicação de doenças tropicais endêmicas transmitidas por vetores existentes nesse meio ambiente; e também como um programa de campanha de campo, junto à população para sua educação sanitária, ensinando-lhe métodos dc higiene pessoal e de esterilização (pasteurização) dos alimentos crus consumidos.

\section{Consideraçōes Finais}

A economia de um país se faz com uma população sadia, com trabalhadores sãos e dispostos para o trabalho, com um programa de prevenção de saúde pública ambiental onde a população de uma região ou país, ou mesmo de uma pequena comunidade, estão livres de en fermidades que coloquem $\mathrm{cm}$ risco em primeiro lugar suas vidas; em segundo, o nível das atividades econômicas c, portanto, a sua formação bruta de capital (Produto Interno Bruto - PIB); c em terceiro, até mesmo a possibilidadc real da queda acentuada ou eliminação do fluxo turístico receptivo internacional, ocasionando reflexos negativos na captação de divisas internacionais, tão vitais para os países de potencial turístico, como o Peru.
A saúde pública ambiental, sempre de caráter preventivo, deve deixar de ser uma preocupação marginal no planejamento turístico de um determinado espaço geográfico, para tornar-se uma preocupação central para qualquer empreendimento turístico, seja de caráter estatal, privado ou misto, para o benefício do desenvolvimento econômico sustentado de uma região, país ou comunidade. O exemplo aqui exposto do caso peruano, no início da década de 90 , é eloqüente quanto a essa assertativa.

É de se propor que os custos ambientais para a sua preservação, que são dos poderespúblicos, sejam em parte também custeados com uma parcela dos lucros dos empresários turísticos, colaborando com o setor público na preservação do meio ambiente.

Assim a preocupação de um governo ao elaborar seu Plano Nacional de Turismo, como agente regulador e incentivador da atividade turística numadeterminada região ou em todo o seu território, não deve somente criar condições para o desenvolvimento de equipamentos e infra-estrutura turística, mas também criar condições de sanidade ambiental, de tal modo que tanto a população, quanto os turistas fiquem imunes do perigo de serem atingidos por epidemias de doenças tropicais, sem vacinas existentes que as debelem fisicamente de imediato, correndo o risco de até morrerem em virtude delas, o que representa um fator inibidor do fluxo turistico internacional.

Através deste estudo pretendeu-se alertar e conscientizar os planejadores do Turismo do setor governamental para tal problema, com o intuito da preocupação com o meio ambiente sano, livre de vetores transmissores de doenças, como o cólera aqui analisada. Tal situação pode na verdade comprometer todo um Plano Nacional de Turismo, calçado somente na infra-estrutura concreta, visível e perceptível aos olhos dos moradores locais e dos turistas, sejam nacionais ou internacionais.

\section{Referências Bibliográficas}

COSTA, Guilherme A. de Moura. 1997. Programas Governamentais de Saíde Pública. Estudo de Caso - O Programa de Controle do Dengue na Costa Rica, Venezuela e Estado de São Paulo (Brasil). Seu Recursos e Custos. O CustoEfetividade no Período de 1990 a 1994. Tese (Mestrado). PROLAM/Universidade de São Paulo.

PERU - 1997 EN NUMEROS - Anuário Estadístico. Consulado geral do Peru. São Paulo.

\section{Recebido em 27/6/99}

Aprovado em $11 / 8 / 99$ 